\title{
Students' Perceptions Toward the Implementation of Quipper School as an E-Learning Platform in Teaching English
}

\author{
Santi Septinawati \\ Universitas Galuh Ciamis \\ santiseptinawati91@gmail.com \\ R. Bunga Febriani \\ Universitas Galuh Ciamis \\ bunga.febriani@gmail.com \\ Wawan Tarwana \\ Universitas Galuh Ciamis \\ wtarwana@gmail.com \\ Syafryadin \\ University of Bengkulu \\ syafryadin@unib.ac.id
}

\begin{abstract}
This article reports the students' perceptions in implementing Quipper School as an elearning platform in teaching English and to know the advantages and disadvantages of it. This study took two sample classes with the overall fifty-three students by using cluster sampling technique and focusing on the survey study method. Twenty questionnaires provided to identify the students' perceptions about quipper school. A depth information appear to be as important to gain more information and continuous responses to explore the advantages and disadvantages of implementing quipper school that have been undertaken by interviewing the students. The findings revealed that the students are comfortable learning with technology and also prefer to use IT. More significantly, The advantages of quipper school keep interaction between teacher and student in and out of the classroom, students still get lesson or review the material even though the teacher is not present in the classroom, and enhances students' learning experiences using new learning system. Besides, quipper school also has disadvantages when it is applied in learning process, such as unstable internet connections, limited facilities (computer) that support learning by using quipper school, and there was no speaking material which it could be implemented in quipper school. It can be noted today learning and teaching can benefit from using quipper school in teaching English, students still get a lesson even though the teacher is not present to provide direct instruction and students can improve their achievement in learning English by reviewing the material wherever and whenever they are.
\end{abstract}

Keywords: students' perceptions, quipper school, e-learning

\section{A. Introduction}

The use of media in teaching and learning is really important, it needs to attract students' attention and to make teaching and learning activities more interesting and also effective (Syahrial \& Syafryadin, 2020; Azwandi, et al. 2020). Development of 
communication technology and social media is currently underway so fast. Any information easily accessed anywhere and anytime through technology devices like smartphones, tablets and laptops. As Information and Communication Technology (ICT) is advancing rapidly, new technology and innovation in teaching and learning have developed accordingly. Joe and Chol (2002) argue that new technology systems and instruments are becoming more and more common and being used for the benefits of educational activities The innovation concerning educational activities brings about opportunities for teachers and students to experience teaching and learning beyond traditional classrooms, that is through ComputerAssisted Language Learning (CALL). One of the most wellknown CALL media is Learning Management System (LMS). In addition, Chapelle (2003) and Anggitasari, et al. (2020) suggest that the use of computer technology in the classroom should bring benefit to learners through enhanced linguistic input. The three types of language input suggested by Chappelle are salience (e.g. interaction with a grammar application), modification (providing any means that help learners to arrive at the meaning, such as through images), and elaboration (providing explanations). QS provides these three types of enhanced learning input. . (Saptani, 2017).

As stated by Saptani (2017), Cahyono (2015) said that One of the roles of the IT in the world of education is with the existence of e-learning. E-learning is learning that uses technology communication and information (ICT) for transforming the learning process between teacher and students. E-learning is learning in which the process takes place uses technology such as internet, computer, audio or video tape. E-learning also can be said as a digital learning process. All of people suppose that e-learning is a Web-based learning in which using browsers to support learning process. Web-based learning is one of implementation from e-learning. One of the media learning available online now is Quipper School.

This study attemps to find out the students' perceptions of quipper school in high school level to see whether it can be as an e- learning platform $n$ teaching English, because it was found that the teacher still had problems in their instructional media in teaching English. Subject matter is not organized well, inappropriate learning methods and teachers have not applied innovative learning media that supports students to learn better, students are not interested in learning so students do not have awareness of independent learning. As a result, learning becomes not effective. This is happened because the teacher was still 
using conventional learning media which is limited to the print module. Meanwhile, In this research Quipper School Can be used to bridge this gap, It aims to empower teachers to help their students by combining quality learning content with an advanced online platform and integration of media and technology to the class can boost students' participation, promote student-centered mode and create positive atmosphere.

\section{B. Literature Review}

Quipper school can be conceptualized within the framework of some literature review concerning the use of quipper school as an e- learning platform in teaching English. technological development gives influence toward learning process. ICT has an influential role to teachers especially in the use of facilities to enrich teaching ability. The use of ICT in teaching and learning makes learning become more effective and also can overcome the limitation of learning resources. According to Hartley (2001), e-learning is the kinds of teaching and learning that enable to deliver materials to students by using internet, intranet, or computer line media. E-learning is technology that is bridge by the internet technology which requires media in order to show materials and also requires communication facilities in order to exchange information between students and teachers. In addition, Rosenberg (2001), stated that "E-learning replaces the use of internet technology to send solution that can improve knowledge and skill. For example, teachers can use devices such as computers, LCD to support teaching process. The use of ICT in teaching and learning makes learning become more effective and also can overcome the limitation of learning resources Computer Assisted Language Learning (CALL) is one of the many tools and techniques that can help improve the students' language competencies. This new technology in language education has increased learner autonomy, creativity, productivity and team work. Computers can be tremendously useful tools for English language instruction. They can process data quickly and integrate voice, music, video, pictures, and text into lessons. They can be programmed to tailor instruction and tests for each individual learner. While there are many potential benefits to be derived from these "machines", the issue now is not whether but how computers should be used for language instruction. Regardless of the speculated disadvantages of using computers for language instruction, advanced by some individuals or groups, computers and CALL materials are already being used for English language instruction and will continue to be used. It can be used as a modern approach towards language teaching and learning in which the computer 
is utilized as an aid to the presentation, and as reinforcement and assessment of material to be learned by usually including substantial interactive materials. According to Chapelle (2003), the use of computer technology in the classroom should bring benefit to learners through enhanced linguistic input. The three types of language input suggested by Chappelle are salience (e.g. interaction with a grammar application), modification (providing any means that help learners to arrive at the meaning, such as through images), and elaboration (providing explanations). Quipper addresses these types of enhanced learning input. Quipper provides a chance for learners to interact with a computer, although this seems limited. Students can only interact with a computer through the lessons and quizzes previously set up by their teachers. the use of Quipper School aims to modernize the way people learn and share knowledge; Quipper School offers a fun way of online learning since it is believed that students learn in different ways. Electronic Grading lessened all the paper works and in just a flash, the teacher can create a class and assignments. Quipper School absolutely saves time and effort on the part of the teacher and the students. Katz (2009) state that the students are more enjoy in using technology and also they are indicating technology inside or outside classroom. Every year the students show the interesting of technology in academic context. Furthermore, the students' responses while using quipper school in class are very positive. The students are comfortable learning with technology and also prefer to use IT in the class. Therefore, this study will give further insight into students' perceptions of implementing quipper school as an e- learning platform in teaching English. This study will attempt to answer these two following questions: 1) What are the students' perceptions toward the implementation of Quipper School as an e-learning Platform in teaching English? 2) What are the advantages and disadvantages of using Quipper School as an e-learning platform in teaching English?

This research is aimed at exploring and answering: 1) the students' perceptions toward the implementation of quipper school as an e-learning platform in teaching English, and 2) the advantages and disadvantages of implementing quipper school as an e- learning platform in teaching English.

\section{Research Methodology}

The research method used in this study was qualitative research method. Creswell (2014, p.232) defines that qualitative methods demonstrate a different approach to 
scholarly inquiry than methods of quantitative research. Although the processes are similar, qualitative methods rely on text and image data, have unique steps in data analysis, and draw on diverse designs. Based on the objective and the problems of this research, the writer decided to use survey study method. According to Nunan and Bailey (2009, p.25), "the overall purpose of a survey is to obtain a snapshot of conditions, attitudes, and/or events of an entire population at a single point in time by collecting data from a sample drawn from that population". Survey study involves systematically gathering enough informations about a particular person, social setting, event, to permit the research to effectively understand how the procces and how the conclusion of the research.

As the data sources, this study was conducted in one of Senior High Schools in Tasikmalaya, West Java. The participants of this study was two sample classes of the eleventh grade of scince class (MIPA-1) which consist of thirty-eight students, and the eleventh grade of social science class (IPS-2) which consist of twenty-five students in the sample classroom. Overall, there were fifty-three students participated in this survey.

To answer the research question, the questionnaires and the interviews were used as the data collection techniques. The questionnaire session was given after three times meeting and implemented after the live lecture to find out their perceptions of quipper school. Twenty items of ten positive statement and ten negative statement includes about students' interests, motivation, expectations, ineffectiveness and difficulties of quipper school itself were provided. Then the interview session was given after answering the questionnaire. The four survey questions of interview were given in focus group interview.

The likert-scale questionnaire items analyzed by using quantification in form of percentage computation as suggested by Hatch and Lazaraton (1991, p.136), the formula of the percentage was as follows:

Proportion $=$

Number of Frequency $x 100$

Total Number

Where as survey questions were analyzed by coding the obtained data, Coding is defined by Charmaz (2006, p.56) as a process by which research data categorized or grouped under a name shorter that also shows similarities with other data. Coding shows how research data are separated, selected and sorted by the researcher to begin the analysis process. and then transcribing the data to get the answer of the second research questions. 


\section{Findings and Discussion}

In the questionnaire session, almost all students from two sample classes stated that they had positive perceptions of a quipper school In term of the first positive questionnaire, "Quipper School interested me for studying English.". From the total number of 28 science male students (MIPA), 15 (53.6\%) students voted agree, from the total number of 25 social science students (IPS), 14 (56\%) students voted strongly agree, It clearly shows that almost all students react positively.

The second questionnaire, "Quipper School is comfortable for me in learning process ", there are $16(56.1 \%)$ of MIPA students voted agree, then $14(56 \%)$ of IPS students voted agree, the writer concluded that the most of students felt comfort with quipper school during the learning process.

The third questionnaire, "Quipper school give me more attention in learning process", there are $14(50 \%)$ of MIPA students chose strongly agree, 15 (60\%) of IPS students chose agree. It shows that most of the student kept attention in learning process by using quipper school.

The fourth questionnaire, "Quipper school motivate me more for studying in and out of the classroom”, 18 (64,3\%) of MIPA students chose strongly agree, 20 (80\%) of IPS students answered strongly agree, This results proven that the implementation of quipper school very motivated the students for their learning process.

The fifth questionnaire, "I find it easier and focused to learn by using video conferencingQuipper school is easy for me and learning process become more organize in and out of the classroom", were chose by 14 (50\%) of MIPA students who voted Agree, $13(52 \%)$ of IPS students chose agree, This results proven that both sample classes of MIPA and IPS assume quipper school is organized well used in and out of the classroom and making easier in their learning process.

According to the sixth questionnaire, "Quipper school gain me materials from it application", there are $18(64.3 \%)$ of MIPA students chose strongly agree, and then there are $15(60 \%)$ of IPS students chose strongly agree too, This results shows that students strongly felt that quipper school application gain them more material in learning English.

Based on the seventh statement, "Quipper school help ,e for studying another subject", $18(64.3 \%)$ of MIPA students answered strongly agree, $15(60 \%)$ of IPS students also 
answered strongly agree, This results proven that most of students felt that quipper school application is very easy in using it although with other subject except English.

According to the eighth questionnaire, "Quipper school is clear and it is easy for understanding the material ", there are 13 (46.4\%) of MIPA students chose strongly agree, then $15(60 \%)$ of IPS students answered agree. This results shows that the material presented in the quipper school application is very clear and easy for them to understand in learning process.

The ninth questionnaire, "Quipper school material is variative and make study more enjoyable”, it was found that $16(57.1 \%)$ of MIPA students chose agree, 15 (60\%) of IPS male students answered strongly agree, This results confirmed that most of the students assume agree to this item.

The last positive questionnaire, "Quipper school help me in learning achievement", there are almost 13 (46.4\%) of MIPA students answered strongly agree, and then 13 (52\%) of IPS students answered agree, This results confirmed that students admitted that they could improve their achievement by using quipper school in learning process.

The next findings described their negative perceptions of quipper school, in term of the first negative questionnaire, "Quipper school makes learning time become more narrow", there are 11 (39.3) of MIPA students chose neutral, and then there are 14 (56\%) of IPS e students chose disagree for this item. It means the use of quipper school does not make the class' learning time narrow.

The second questionnaire, "Quipper school is not effective because lack of interaction between students and instructor", from this item, it indicated there are 15 (53.6\%) of MIPA students chose neutral, 16 (64\%) of IPS students chose disagree for this item. This findings inferred that learning process by using quipper school was effective by its interactions.

The next findings for the statement, "Quipper school makes the material unpresented well by the teacher", it was found there are 18 (64.3\%) of MIPA students answered disagree, then $19(76 \%)$ of IPS students answered disagree too. It means the teacher conveyed the material well in teaching process by using quipper school.

The fourth questionnaire, "Quipper school is not effective because teacher and student cannot always meet face- to- face in classroom directly", it was found there are 13 (46.4\%) MIPA students answered disagree, next there are 20 (80\%) IPS students also 
voted disagree, This findings shows that most of students react negatively for this item. The teacher and students can still have face-to-face learning and teaching process through quipper school sometime can be implementing out of the classroom.

The fifth questionnaire, "Quipper school is lack of support for learning process because the information in material untransferred all", it found there are 19 (67.9\%) of MIPA students chose disagree, then $20(80 \%)$ of IPS students also chose disagree to this $\mathrm{i}$ tem, This results inferred that most of the students agree that quipper school support the learning process because teacher presented well the material by using quipper school.

Concerning the sixth questionnaire, "Quipper school requires good electric facilities to be in use in classroom", there are 18 (64.3\%) MIPA students voted disagree, then 13 (52\%) IPS students voted neutral, This results clearly shows that learning process by using quipper school required normally electricity usage.

Based on the seventh questionnaire, "Quipper school requires stable internet connection to be in use in the classroom", it was found there are $21(75 \%)$ MIPA students answered strongly agree, then 17 (68\%) of IPS students answered strongly agree too, This findings clearly answered that for both sample classes, the implementation of quipper school required a stable internet connection.

According to the eighth questionnaire, "I don't understand well how to use quipper school in learning process", it was found there are 18 (64.3\%) MIPA students chose disagree, the next there are $16(64 \%)$ of IPS students also answered disagree From this results, it can be deduced that from two sample classes very understood to the use of quipper school.

The ninth statement, "Presentations using quipper school are facility is difficult for me than without quipper school facilities", from this item, it was found there are 16 (56.1\%) of MIPA students voted disagree, and $16(64 \%)$ of IPS students voted disagree too. From the percentage above, it can be concluded that both sample classes students is not felt difficult to present the presentations by using quipper school.

The last negative questionnaire, "Quipper school facilities is very costly for me", it was found there are $22(78.6 \%)$ MIPA students chose disagree, and the last there are $15(60 \%)$ of IPS students voted neutral. Referring to the result above, almost students argue that the implementation of quipper school is not expensive. 
From all the findings concerning the first research question, it can be concluded that the result that found in science class (MIPA-1) is almost students perceptions are positive on implementing quipper school in teaching English. Furthermore, the results that found in social class (IPS-2) concluded that almost students' perceptions are also positive about the use of quipper school as an E-learning platform in teaching English. These research findings is relevant with Katz (2009) stated that the students are more enjoy in using technology and also they are indicating technology inside or outside classroom. Every year the students show the interesting of technology in academic context. Furthermore, the students' responses while using quipper school in class are very positive. The students are comfortable learning with technology and also prefer to use IT in the class. In conclusion, by having more positive responses in this research, the writer argues that the implementing of quipper school is the best implementation as an e- learning platform in teaching English. As an online platform,Quipper School can be used either in the classroom or outside the classroom.

Also, a depth information appear to be as important to gain more in-depth information and continuous responses to explore the advantages and its disadvantages of quipper school that have been undertaken by interviewing the students. The findings revealed more significantly, students argue the main advantages and disadvantages of quipper school in learning English process. The quipper school that can be used as E-learning platform in teaching English now considered an advantageous way to make the learning process more enjoy, interest and comfortable, This bridging result and the theory which in line with the theory by Katz, 2009.

The quipper school allows students to still access or get a lesson even though the teacher is not present to provide direct instruction in the classroom, the students can indicating technology inside or outside classroom. This is line with the theory by Rahmawati. Et.al (2015) which stated that "Teacher and students can interact directly through the massage that provided by Quipper school". And the theory which stated by Mulyono (2016) "In Quipper, teachers and students are given an opportunity to get engaged into interpersonal communication. The 'message' and 'announcement' features help teachers to interact with colleagues and students".

The quipper school makes teacher more creative to utilize information technology in accordance with the development of today Era. Quipper school also enhance teachers' 
creativity, and enhance learning experience using new learning system. This is relevant with Moron (2015) stated that by leveraging the mobile internet, the use of Quipper School aims to modernize the way people learn and share knowledge.

The quipper school enhances students' learning achievement by the material and variative exercises, the students can review the material or assignment from the teacher wherever and whenever, by monitor all the learning activity including students' score from the assignment given by the teacher and the materials that presented in quipper school supported the school's English curriculum. This bridging the results and the theory which in line with the theories by (Rahmawati, R. et al, 2015 and Mulyono, 2016).

The quipper school is convenient e-learning platform in teaching English. By implementing quipper school provides a chance for them to interact with a computer, automatically they prefer using technology in class while learning. This is also similar to the theory according to Hartley (2001) that. E-learning is technology that is bridge by the internet technology which requires media in order to show materials and also requires communication facilities in order to exchange information between students and teachers. Besides, quipper school also has weakness or disadvantage when it is applied in learning and teaching process, such as unstable internet connections, limited facilities (computer) that support learning by using quipper school, and there was no speaking material which it could be implemented in quipper school.

It can be noted today learning and teaching can benefit from using quipper school as an e- learning platform in teaching English, students still access or get a lesson even though the teacher is not present to provide direct instruction in the classroom, the students can indicating technology inside or outside classroom, so that learning can be done and students can improve their achievement in learning English by reviewing the material wherever and whenever they are.

The results of this presents study compared with previous studies in order to enrich, strengthen, or mark some contrary things to previous studies on quipper school. The first previous study was conducted by Jeoffrey G. Guillen, M.A. Ed., from Cebu Normal University. This study analyzed the effectiveness of Quipper School in the enhancement of the reading comprehension competencies in English 8 (3rd Quarter). The students have acquired and enhanced the required reading comprehension competencies. The research 
design applied by this researcher is pre-experimental method of research.Pre-experimental method. Quipper school enhances the reading comprehension of the students, quipper school considered as a supplemental strategy to improve the academic performance of student. As the result, the strategy used in this previous study to improve students achievement especially in reading comprehension is positive toward implementing quipper school. Similar with this present study about the students' learning achievement by the assignment from the teacher on how the students can answer the reading question easily and it is one of the advantages that was found by the writer from this research. In order to enrich the previous study noted the other advantages and disadvantages of implementing quipper school. For the advantages those are: 1) the quipper school make the learning process more enjoy, interest and comfortable, and also the students can indicating technology inside or outside classroom, 2) the quipper school allows students to still access or get a lesson even though the teacher is not present to provide direct instruction in the classroom, the students can indicating technology inside or outside classroom, 3) the quipper school makes teacher more creative to utilize information technology in accordance with the development of today Era. Quipper school also enhance teachers' creativity, and enhance learning experience using new learning system, 4) the quipper school is convenient e-learning platform in teaching English, quipper school provides a chance for students to interact with a computer, automatically they prefer using technology in class while learning. Besides the disadvantages that can be noted as follows: 1) the quipper school have the problematic with unstable internet connections and limited facilities (computer) that support quipper school. And 2) The quipper school is also there was no speaking material which it could be implemented in quipper school.

Further comparison with the second previous study Munawaroh, from UIN Sunan Ampel Surabaya. The title is, "Classroom Interaction in Teaching English Using Quipper School at State Vocational High School 2 Buduran Sidoarjo". She found the effectiveness of Quipper School on her thesis. The study used descriptive qualitative method. In this study, the researcher found out the followings: first, the discourse of the facilitator occurred in the process; second, the discourse of the students happened every time he/she asked, wrote study note and answered the question. Moreover, using Quipper School in classroom interaction's pattern is not all essentially used; third, there are three patterns: facilitator's interaction to the whole class, whole class interaction to the facilitator, and 
learners interaction to learners are included in the teaching process. In this study, the researcher concluded that Quipper School was good for teaching English as a supplemental tool.

Regarding to the present study, the writer found the advantages almost identical to those previous study about the feature of quipper school is operated well by the teacher and students during the learning process. But the writer regards to add findings from that have not been discovered from previous study as follows: 1) the quipper school make the learning process more enjoy, interest and comfortable, and also the students can indicating technology inside or outside classroom, 2) the quipper school makes teacher more creative to utilize information technology in accordance with the development of today Era. 3) quipper school also enhance teachers' creativity, and enhance learning experience using new learning system, 4) the quipper school is convenient e-learning platform in teaching English, quipper school provides a chance for students to interact with a computer, automatically they prefer using technology in class while learning. To enrich the previous study, the writer noted some disadvantages of quipper school based on the findings of present study as follows: 1) the quipper school have the problematic with unstable internet connections and limited facilities (computer) that support quipper school. And 2) The quipper school is also there was no speaking material which it could be implemented in quipper school.

The third comparison of previous study by Manggiasih Nurdiana, The title is, "The Use of Quipper School as an E-learning Platform in teaching English to the Tenth Grade Students of MAN 2 Ponorogo in Academic Year 2015/2016”. In this article,he stated the effectiveness of using Quipper School in his study. He used descriptive qualitative to describe how Quipper School was used and what its advantages and disadvantages are. Interview and observation are used as techniques in the gathering of data.The results were the following: first, ICT-based learning initiated QS; second, the advantage of Quipper School was that it made learning activity fun and enjoyable, accessible, effective, and affordable; third, the only disadvantage of using Quipper School was the limitation of the Internet connection faced by the students during the implementation.

The previous study include the potential advantages and disadvantages as a target research, but the writer regards to add findings from previous study, the advantages as 
follows : 1) the quipper school allows students to still access or get a lesson even though the teacher is not present to provide direct instruction in the classroom, the students can indicating technology inside or outside classroom, 2) the quipper school enhances students' learning achievement by the material and variative exercises, the students can review the material or assignment from the teacher wherever and whenever, by monitor all the learning activity including students' score from the assignment given by the teacher and the materials that presented in quipper school supported the school's English curriculum. Besides the disadvantages that can be added as follows: 1) the quipper school have limited facilities (computer) that support quipper school. And 2) The quipper school is also there was no speaking material which it could be implemented in quipper school.

\section{Conclusions and suggestions}

Finally, the answered for the first research question regarding students' perceptions toward the implementation of quipper school as an e- learning platform in teaching English was according to above procedure. So from the above procedure, the students gave their perceptions both positive and negative provided by the writer in the questionnaire form. Based on the data, as the result, almost all students from two sample classes gave a positive perceptions. The writer argues that by having more positive responses, the implementing of quipper school is the best implementation as an e- learning platform in teaching English.

Regarding the second research question about the advantages and disadvantages of quipper school, the writer states that the students generally pleased and have a high enthusiasm in using quipper school. They assume that quipper school keep interaction between teacher and student in and out of the classroom in learning process, students still access or get lesson or review the material even though the teacher is not present in the classroom, motivate students to learn because they felt interested and comfortable in using the quipper school, enhances teachers' creativity, enhances students' learning experiences using new learning system. Besides, quipper school also has weakness or disadvantage when it is applied in learning and teaching process, such as unstable internet connections, limited facilities (computer) that support learning by using quipper school, and there was no speaking material which it could be implemented in quipper school. 
Regarding to the conclusions above, the writer suggests to the institutions, teachers, and the further researcher who will do research in the same field.

For the institutions, the schools should attempts to facilitate the teaching and learning activities, especially for English lesson which requires conductive conditions that needs competent teachers, supporting teaching media such as computer, internet access, projector, etc.

For the teachers, the writer suggest the teacher also use video online for adding lesson in Quipper School and another flash media. In Quipper School there is menu for uploading the movie clip or video. So, the class will be alive and more interesting. Another suggestion for the teacher who has not used Quipper School is better for the teacher used Quipper School only in online learning. Quipper School will be not useless. Quipper School is one of e-learning platform that really help the teacher and students in easily the learning activities. Lastly, There are a lot of topics that have not been revealed in Quipper School. This research generally focused students' responses in using Quipper School. Other researcher can carry out research in comparing the lesson in Quipper School with K13 book and the deep research in Quipper School software. By using technology based learning, the teacher should be able to play the role as a good model, counsellor and motivator for the students too.

Last, the result of this research provides a significant learning English by using quipper school. In this regard, Other researcher can carry out research in comparing the lesson in Quipper School with K-13 book and the deep research in Quipper School software.. Finally, the writer recommends for further researchers who want to conduct the same research, should conduct the research in longer period to get more accurate data.

\section{REFERENCES}

Anggitasari, M., Tarwana, W., Febriani, R. B., \& Syafryadin, S. (2020). Using Wattpad to Promote the Students' Responses to Literary Works: EFL College Students' Perspectives and Experiences of Enjoying Short Stories. Jadila: Journal of Development and Innovation in Language and Literature Education, 1(2), 182-192.

Azwandi, A., Harahap, A., \& Syafryadin, S. (2019). Penyuluhan dan pelatihan ictenhanced teaching-learning sebagai model pengembangan profesional guru di kota 
Bengkulu. Jurnal Pengabdian Masyarakat Ilmu Terapan (JPMIT), 1(1).

Chapelle, C. (2003). English language learning and technology: Lectures on applied linguistics in the age of information and communication technology (Vol. 7). Amsterdam, Philadelphia: John Benjamins Publishing.

Charmaz, K. (2006). Constructing grounded theory: A practical guide through qualitative analysis. London: Sage.

Creswell, J.W. (2014). Research Design: Qualitatitive, quantitative, mix methods approaches. $\left(4^{\text {th }} \mathrm{ed}\right.$.). Thousand Okas, CA: Sage.

Darin E. H. (2001). Selling E-Learning, American Society for Training and Development.

Guillen, J.G. (2018). Quipper school based English teaching, 6 (3), 875-891.

Hatch, E. \& Lazaraton, A. (1991). The research manual: Design and statistics for apllied linguistics. Massachusetts: Heinle Publihers.

Joo, Y, J., Bong, H.J., Chol. (2002); Self-Effiacy for selfregulated learning, academic selfeffiacy and internet selfeffiacy in web based instruction. ETR\&D,Cilt. 48(2), 5-17.

Likert, R. (1932). A technique for the measurement of attitudes. Archives of Psychology, 22 (140), 1-55.

Manggiasih, N.F. (2016). The use of Quipper School as an E-learning platform in teaching English to the tenth grade students of MAN 2 Ponorogo in academic year 20152016. http://etheses.iainponorogo.ac.id/1458/ Retrieved October 7, 2017, from https://goo.gl/Dd3jh1

Morron, A. (2015). The effect of Quipper School on the performance of grade 7 students of Bacoor national high school - Gawaran in Teaching Mathematics, Retrieved October 7, 2017, from https://goo.g1/t3ZpuX

Mulyono, H. (2016). Using Quipper as an online platform for teaching and learning ENglish as a foreign. Teaching English with Technology, 16(1), 59-70.

Munawaroh, S. (2016). Classroom interaction in teaching English using Quipper School at Vocational High School 2 Buduran Sidoarjo. Undergraduate thesis, UIN Sunan Ampel Surabaya. Retrieved June 15, 2017, from http://digilib.uinsby.ac.id/13288/

Nunan, D. And Bailey, K.M. (2009). Exploring second language classroom research. Sherrise Roehr.

Rahmawati, R. et al. (2015). Keefektifan penerapan e-learning-Quipper School pada pembelajaran akuntansi Di SMA Negeri 2 Surakarta. Tata arta Journal UNS.

Richard, N.K. (2009). The ECAR Study of undergraduate students and informations technology (Educause:Colorado. Rosdakarya, 71 (1), 51. 
Rosenberg, M..J. (2001). E-learning:Strategies for delivering knowledge in the digital age.USA:McGraw-Hill Companies.

Saptani, D. A. (2017). Teachers ' Perception towards the Use of Quipper School in Teaching English. Proceeding of Conaplin 9, 82, 233-235.

Syahrial, S., \& Syafryadin, S. (2020). Pelatihan menjadi guru bahasa Inggris kreatif dan milenial di sekolah menengah pertama bengkulu Tengah. Jurnal Inovasi Pengabdian Masyarakat Pendidikan. 1(1). 18-35. 